\title{
Extreme ameloblastoma of the mandible with hypoproteinemia. A case report and review of clinicopathological features
}

\author{
Swetha Acharya ${ }^{1}$, Abhijit Joshi ${ }^{2}$, Amsavardani S.Tayaar ${ }^{3}$, K. Gopalkrishnan ${ }^{4}$ \\ ${ }^{1}$ M.D.S. Assistant Professor. Department of Oral Pathology and Microbiology. S.D.M College of Dental Sciences and Hospital, \\ Dharwad 580 009, Karnataka, India \\ ${ }^{2}$ M.D.S. Assistant Professor. Department of Oral and Maxillofacial Surgery. S.D.M College of Dental Sciences and Hospital, \\ Dharwad 580 009, Karnataka, India \\ ${ }^{3}$ M.D.S. Professor \& Head. Department of Oral Pathology and Microbiology. S.D.M College of Dental Sciences and Hospital, \\ Dharwad 580 009, Karnataka, India \\ ${ }^{4}$ M.D.S., F.D.S.C.R.S. Professor \& Head. Department of Oral and Maxillofacial Surgery. S.D.M College of Dental Sciences and \\ Hospital, Dharwad 580 009, Karnataka, India
}

Correspondence:

Department of Oral Pathology and Microbiology

S.D.M College of Dental Sciences and Hospital, Dharwad 580 009, Karnataka, India

e-mail: sbacharya@gmail.com

Received: $02 / 12 / 2010$

Accepted: 28/02/2011

\begin{abstract}
Acharya S, Joshi A, S.Tayaar A, Gopalkrishnan K. Extreme ameloblastoma of the mandible with hypoproteinemia. A case report and review of clinicopathological features. J Clin Exp Dent. 2011;3(4):e343-7. http://www.medicinaoral.com/odo/volumenes/v3i4/jcedv3i4p343.pdf
\end{abstract}

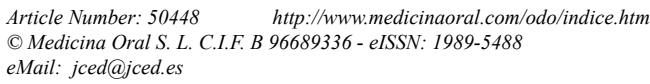

\begin{abstract}
Ameloblastoma is a tumor of odontogenic epithelium. It has an intermediate malignant potential, thus positioning it in a gray zone between benign and malignant neoplasms. Invasive ameloblastomas of excessive size are rarely confronted. Although these ameloblastomas are benign, they are life threatening. Many have eventuated in death due to airway obstruction, starvation from restriction of feeding, and complications of hypoproteinemia. These tumors cause significant expansion of skin and lips [tissue expanders]. Due to its metabolic demands, a tumor of enormous size will have numerous feeding vessels. Patients with extreme ameloblastomas are usually from rural areas of developing countries who delay the treatment due to fear of surgery. We present a case of extreme ameloblastoma in a 35 year old female which was a consequence of patient negligence. The tumor reached an enormous size over 10 years causing gross facial deformities and posed considerable problems in management.
\end{abstract}

Key words: Extreme ameloblastomas, invasive ameloblastomas, mandible. 


\section{Introduction}

Ameloblastomas are benign, locally aggressive, polymorphic neoplasms that consist of proliferating odontogenic epithelium (1). Because of its slow and asymptomatic growth, patients seek treatment only after the lesion has grown remarkably large (2). Neglected ameloblastomas may become enormous and cause gross facial deformities that pose considerable problems in management (3). An uncommon case of extreme ameloblastoma with hypoproteinemia and anemia is presented here.

\section{Case Report}

A 35 year old female reported to our hospital with a complaint of a huge swelling on the left side of the face. She had first noticed the swelling 10 years ago which was painless with minimal extraoral manifestation. The patient neglected the swelling owing to its painless nature and slow growth. Biopsy was performed in the year 2000 at another hospital and was reported as dentigerous cyst with an ameloblastoma. The patient reported to our hospital in 2009 with a huge extraoral swelling on the left side of her face, intraoral discharge and loss of taste sensation.

On physical examination, patient was moderately built and under nourished. She complained of mild fatigue. Her extremities were slightly edematous. On local examination, a large soft to firm swelling measuring approximately $15 \times 10 \mathrm{~cm}$ as found in the left cheek, mandible and submental region (Fig.1). Prominent dilated veins were noticed on the surface of the lesion. Skin over the swelling appeared stretched. Intraorally a

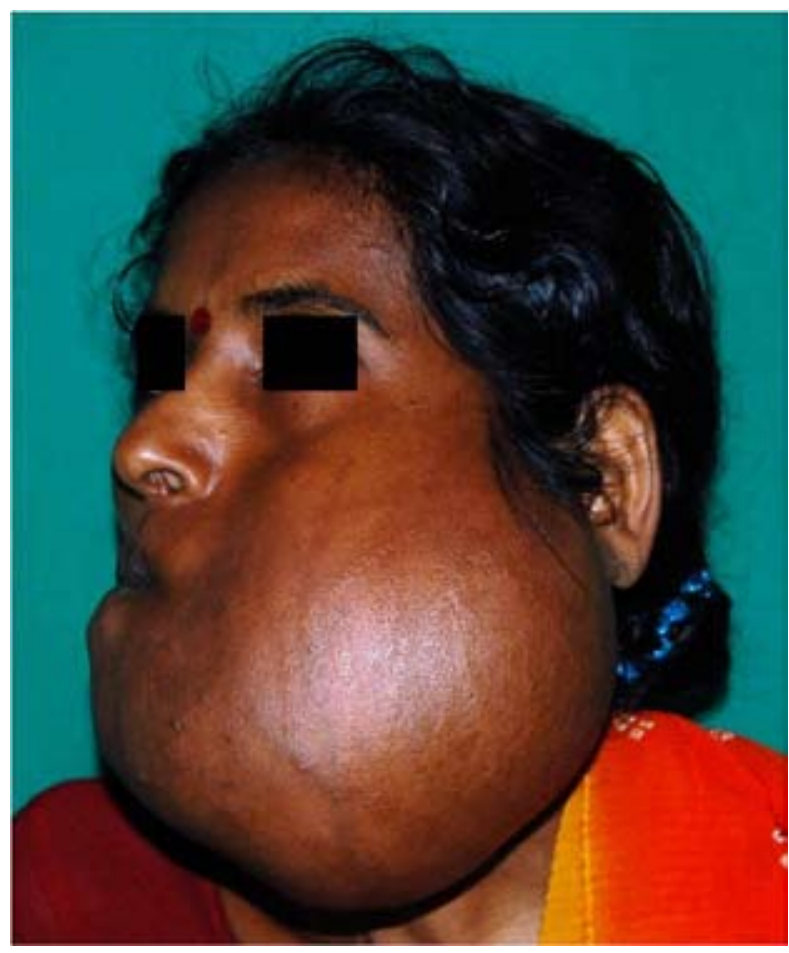

Fig. 1. Preoperative facial appearance (profile view) massive swelling was noticed in the floor of the mouth, pushing the tongue to the contralateral side. Tongue movements were restricted. Crowding and extrusion of lower anterior and premolars were observed. Leakage of serum like fluid was observed from the fistula located at the center of the tumor. The patient had no spontaneous pain or paresthesia on the affected side and mouth opening was adequate.

Radiographic examination revealed a multilocular radiolucency from left condyle and coronoid process to right premolar region. Computed tomography scan revealed a large expansile osteolytic lesion of left mandibular origin, approximately measuring about $15 \times 12 \mathrm{~cm}$ in size, showing multiloculated cystic and solid soft tissue components. Superiorly, it was extending up to infratemporal fossa and inferiorly up to the level of thyroid cartilage. The scan also showed bucco-lingual and antero-posterior expansion with endosteal scalloping, gross cortical thinning with areas of dehiscence. Internal bony fragments were noted resulting in soap bubble appearance of the lesion (Fig.2). There was compromise in the nasopharyngeal airway due to the lesion.

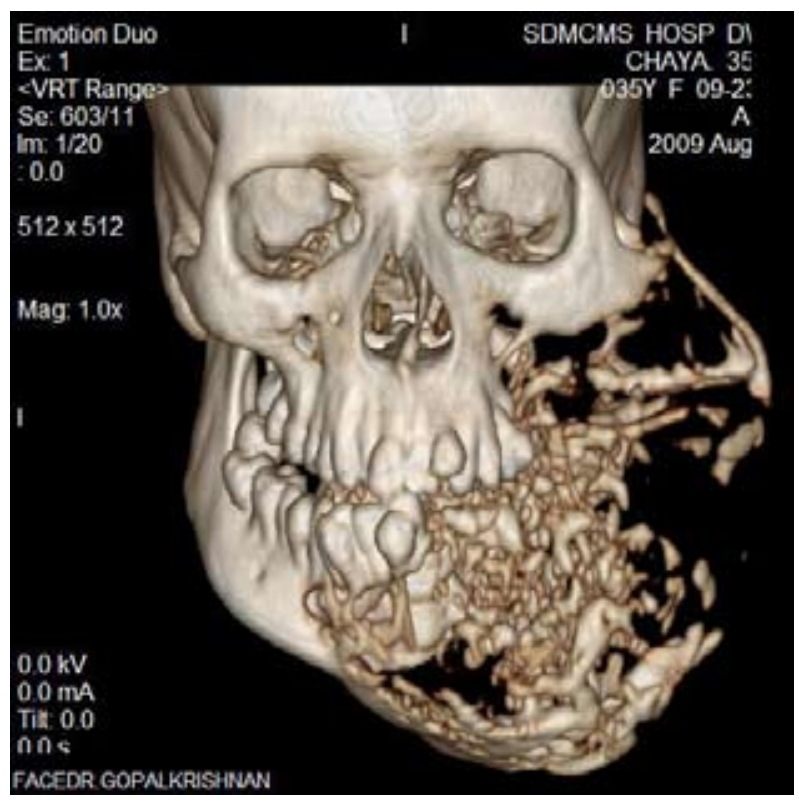

Fig. 2. Computed Tomography scan showed gross cortical expansion with areas of dehiscence. Internal bony fragments were noted resulting in soap bubble appearance of the lesion.

On biopsy, the tumor was diagnosed histologically as plexiform ameloblastoma. After hospitalization, medical examination revealed mild hypoproteinemia and anemia (Table 1). Patient gave no history of polyuria, polyphagia, polydipsia, diarrhea and abdominal pain. Proteinuria, hematuria, oliguria, azotemia, hypertension, liver disorders were ruled out by clinical examination and investigations. Detailed history, clinical examination and investigations assisted to exclude conditions like protein losing gastroenteropathy, nephritic syndrome, diabetes e344 


\begin{tabular}{llll}
\hline Hemoglobin & $9.6 \mathrm{gm} \%$ & Direct Bilirubin & $0.1 \mathrm{mg} \%$ \\
\hline Bleeding time & $1 \mathrm{~min} 30 \mathrm{sec}$ & SGPT & $8.8 \mathrm{IU} / \mathrm{L}$ \\
Clotting time & $5 \mathrm{~min} 10 \mathrm{sec}$ & Serum total protein & $5 \mathrm{gm} / \mathrm{dl}$ \\
Packed cell volume & $33 \%$ & Albumin & $1.9 \mathrm{gm} / \mathrm{dl}$ \\
Erythrocyte segmentation rate & $65 \mathrm{~mm} / \mathrm{hr}$ & Globulin & $3.1 \mathrm{gm} / \mathrm{dl}$ \\
Total White cell count & $13,800 / \mathrm{mm}^{3}$ & A: G ratio & $0.6: 1$ \\
Platelet count & $5.141 \mathrm{lakhs} / \mathrm{mm}^{3}$ & Sodium & $134 \mathrm{mEq} / \mathrm{Lt}$ \\
Random blood sugar & $69 \mathrm{mg} \%$ & Potassium & $3.6 \mathrm{mEq} / \mathrm{Lt}$ \\
Urea & $13 \mathrm{mg} \%$ & Chloride & $96 \mathrm{mEq} / \mathrm{Lt}$ \\
Creatinin & $0.8 \mathrm{mg} \%$ & Urine analysis & $\mathrm{NAD}$ \\
Total bilirubin & $0.3 \mathrm{mg} \%$ & & \\
\hline
\end{tabular}

min: minutes; secs: seconds; SGPT: Serum Glutamic - Pyruvic Transaminase; A:G: Albumin: Globulin ratio; NAD: No abnormality detected.

Table 1. Results of the initial laboratory investigations

mellitus, hepatic disorders and malnutrition, which frequently cause hypoproteinemia.

The tumor was resected enbloc in August 2009 at the craniofacial unit, of our hospital. The tumor was approached via a lip split and a submandibular incision was made below the inferior extent of the lesion. The lower lip and overlying soft tissues were decollated from the tumor. Integrity of the tumor was preserved at all times. The entire tumor mass along with ipsilateral mandible was resected in toto. The defect was closed primarily and reconstruction was deferred for a later stage. The resected tumor measured $15 \times 12 \times 10 \mathrm{~cm}$ and weighed 1350 grams. The histologic diagnosis of the lesion was confirmed as plexiform ameloblastoma (Fig.3). Interstitial cysts were located throughout the large cyst. A large volume of fluid was retained in these cysts.

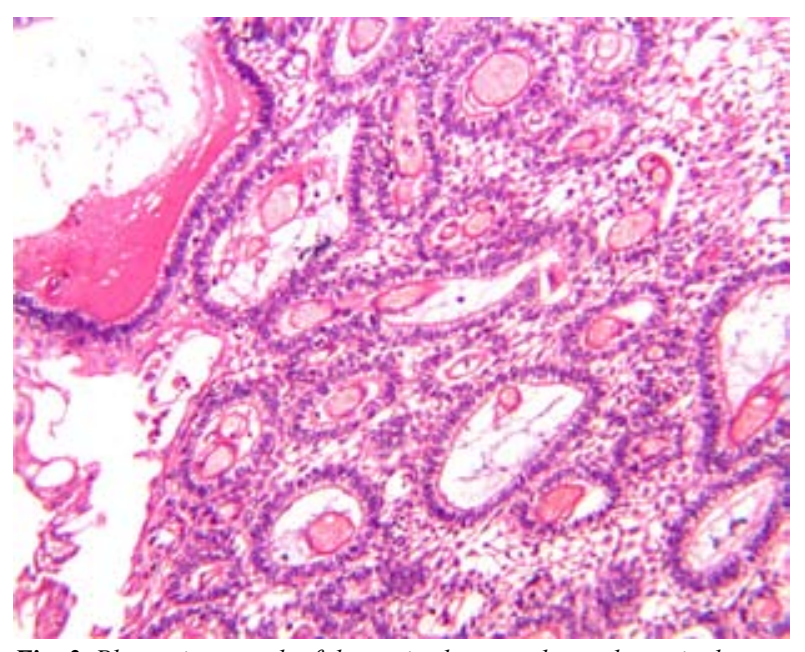

Fig. 3. Photomicrograph of the excised tumor shows the typical pattern of plexiform ameloblastoma.

\section{Discussion}

The term "giant"/ "extreme" ameloblastoma should be reserved for lesions that are truly large and that cause gross asymmetry and regional dysfunction (4). To some extent regional dysfunction like airway obstruction, masticatory and swallowing difficulties were observed in the present case. In recent times it is uncommon to find a large ameloblastoma involving half of the mandible because of early detection owing to the easy access to the investigating aids (panoramic radiograph) (5). Till date there have been ten reported cases $(2,4-8)$ of extreme ameloblastoma with hypoproteinemia, including the present case (Table 2). All reports were of large tumors involving half of the mandible, and they presented with mouth ulcers or fistula. Histological diagnosis in these ten cases was either follicular or plexiform type of ameloblastoma.

Large ameloblastomas can cause loss of occlusal function and difficulty with food ingestion (5). Therefore, poor nourishment can be a cause of hypoproteinemia. Patients also may be at risk for hemorrhage due to ulceration and can develop symptoms of anemia (2). In the present case patient experienced significant weight loss, hypoproteinemia and anemia (not due to hemorrhage). Apart from poor nourishment, patient with markedly progressed ameloblastoma develop hypoproteinemia due to protein loss into the cystic spaces of the tumor, which then leaks it out through the mouth. It has been cited that two cases of large ameloblastomas with hypoproteinemia, which, after removal showed significant increase in serum protein levels, thus suggesting plasma proteins leaked through the oral fistulas of the tumors. (5).

Two factors are presumed to be the cause for hypoproteinemia in large cystic ameloblastoma: the cyst wall acting as a semipermeable membrane; and the leakage of intracystic fluid directly through an opening formed in the cyst wall (2). Some authors propose that odontogenic cysts possess the qualities of a semipermeable membrane and thus show ability to positively transfer protein (6). The albumin level of odontogenic cyst fluid is almost the same as that of serum albumin. This might be due to the molecular weight of albumin being less 


\begin{tabular}{|c|c|c|c|c|c|c|c|c|c|c|c|c|}
\hline Reference & Year & Age & Sex & Location & Tumor size & Nourishment & $\begin{array}{l}\text { Ulceration/ } \\
\text { fistula }\end{array}$ & Transudate & TP & ALB & $\mathbf{H b}$ & $\begin{array}{l}\text { Histological } \\
\text { type }\end{array}$ \\
\hline (2) & 1991 & 39 & $\mathrm{~F}$ & $\begin{array}{c}\text { Left } \\
\text { Mandible }\end{array}$ & $11 \times 10 \times 6 \mathrm{~cm}$ & Normal & + & + & 3.1 & 1.6 & 6 & Plexiform \\
\hline (4) & 1999 & 53 & $\mathrm{~F}$ & $\begin{array}{c}\text { Left } \\
\text { Mandible }\end{array}$ & $\begin{array}{c}15.2 \mathrm{x} 11.4 \mathrm{x} \\
12 \mathrm{~cm}\end{array}$ & Poor & & NA & 3.4 & 1.6 & $\begin{array}{l}\mathrm{Ht} \\
22\end{array}$ & Plexiform \\
\hline (5) & 1977 & 57 & M & $\begin{array}{c}\text { Left } \\
\text { Mandible }\end{array}$ & $\begin{array}{l}\text { Mental region } \\
\text { to ramus of } \\
\text { mandible }\end{array}$ & Poor & + & + & 3.6 & 1.4 & 6.5 & Follicular \\
\hline (5) & 1977 & 62 & $\mathrm{~F}$ & $\begin{array}{c}\text { Right } \\
\text { Mandible }\end{array}$ & $\begin{array}{l}\text { Rt wisdom } \\
\text { tooth to Lt } 1 \mathrm{st} \\
\text { premolar tooth } \\
\text { region }\end{array}$ & Poor & + & + & 3 & 1.5 & 7 & Plexiform \\
\hline (5) & 1990 & 33 & M & $\begin{array}{c}\text { Left } \\
\text { Mandible }\end{array}$ & $\begin{array}{l}\text { Rt cuspid tooth } \\
\text { to Lt mandibular } \\
\text { condyle }\end{array}$ & Poor & + & + & 3 & 1.2 & 6.8 & Follicular \\
\hline (5) & 2005 & 53 & M & $\begin{array}{c}\text { Right } \\
\text { Mandible }\end{array}$ & $14 \times 11 \times 10 \mathrm{~cm}$ & Normal & + & + & 3.4 & 2.0 & 13.1 & Follicular \\
\hline (6) & 1985 & 30 & $\mathrm{~F}$ & $\begin{array}{c}\text { Left } \\
\text { Mandible }\end{array}$ & $15 \times 14 \times 12 \mathrm{~cm}$ & Poor & + & + & 2.7 & 1.6 & $\begin{array}{c}\mathrm{Ht} \\
39.9\end{array}$ & Plexiform \\
\hline (7) & 1995 & 73 & M & $\begin{array}{c}\text { Left } \\
\text { Mandible }\end{array}$ & $11 \mathrm{x} 11 \mathrm{x} 14 \mathrm{~cm}$ & Poor & + & + & 3.4 & 1.8 & 3.5 & Plexiform \\
\hline (8) & 1997 & 62 & $\mathrm{~F}$ & $\begin{array}{c}\text { Left } \\
\text { Mandible }\end{array}$ & $17 \times 15 \times 13 \mathrm{~cm}$ & Poor & NA & NA & NA & NA & NA & Plexiform \\
\hline $\begin{array}{l}\text { Present } \\
\text { case }\end{array}$ & 2009 & 35 & $\mathrm{~F}$ & $\begin{array}{c}\text { Left } \\
\text { Mandible }\end{array}$ & $\begin{array}{l}\text { Rt 1st premolar } \\
\text { to Lt mandibular } \\
\text { condyle }\end{array}$ & Poor & + & + & 5.0 & 1.6 & 9.6 & Plexiform \\
\hline
\end{tabular}

TP: Total protein; ALB: Albumin; HB: Hemoglobin; Rt: Right; Lt: Left; Ht: Hematocrit; NA: not available.

Table 2. Ten reported cases of extreme ameloblastoma with hypoproteinemia

than that of globulin; allowing easy passage through the membrane. Ameloblastoma is also odontogenic, and cyst formation is often found in patients with this disorder. In this condition, it is conceivable that protein permeates through the cyst wall and is transferred into the cystic cavity (5).

Undertaking surgery on a hypoproteinemia patient involves certain risks. Pulmonary edema and other problems involving the retention of fluids caused by lowering of the colloidal osmotic pressure may occur. With the exception of renal hypertension or hypoproteinemia caused by hepatic disorders and malnutrition, the surgical risk involved in patients having leakage- induced hypoproteinemia is minimal (6). Hypoproteinemia can sometimes be improved by the administration of protein and albumin preparation, and tissue coagulants can be used for hemorrhage, but this does not substitute for excision of the tumor (2).
At first sight, surgical management of giant ameloblastoma of the mandible poses formidable difficulties at operation because of hazard to the airway, possibility of severe hemorrhage, and postoperative facial deformity. Preoperative tracheostomy has been suggested by several authors. Anand et al. (9), have stated that prophylactic tracheostomy might be life - saving for such patients.

In situations where tracheostomy is avoided, Daramola et al. (10), have suggested suturing the muscles of the tongue to a Kirschner wire or the metal support of a bone graft and to leave the nasotracheal tube in position for up to 36 hours postoperatively. According to them, the Kirschner wire formed a temporary splint, which made it possible for the patient to breathe and eat more easily. In our surgery, a prophylactic tracheostomy was not performed. The lingual musculature was secured using heavy prolene sutures to the mandible on the unresected side. e346 
by some authors to reduce intraoperative blood loss and aid in dissection. We did not perform any such ligations since perfusion to the skin was important postoperative to avoid any cutaneous necrosis. Reconstruction was deferred to a later stage. Zemann et al. (11), recommends immediate reconstruction as the treatment of choice after radical surgical excision of extreme ameloblastoma since 1-step procedure decreases the number of surgeries and allows earlier prosthetic rehabilitation.

Great attention has been focused in the literature on the extent of the operation and the postoperative recurrence rate, but little mention is made of the mortality and morbidity that may accompany such operations. Morbidity and mortality has been mainly attributed to asphyxia due to tongue fall, postoperative infections and hemorrhage from external carotid artery and pterygoid plexus of veins. Asphyxia due to falling back of the tongue is due to removal of central portion of the mandible together with its origins of several muscles of the tongue. Cook and Singh (12), observed a 15\% rate of operative mortality in mandibular resections for ameloblastoma in their series, while Anand et al. (9), reported 3 deaths in 48 operations. The protocol used for our patient was as follows: preoperative improvement of the patient's systemic condition which included high protein diet through Ryles tube, preoperative chest physiotherapy and hematinic syrups. Intraoperative protocol followed was nasotracheal fibreoptic intubation, injection pause, hypotensive anesthesia. The patient received a total of $1050 \mathrm{ml}$ of whole blood intraoperatively. The patient was extubated the following day. A hand held Doppler was used to assess the skin perfusion. Suture removal was performed on the tenth postoperative day. The patient's general condition has grossly improved in the subsequent visits. Her protein levels were normal and hemoglobin had risen to a healthy $11.3 \mathrm{gm} \%$.

Ameloblastomas of excessive size are rarely confronted. Development of monstrous size is indicative of ameloblastomas relentless growth. Extensive ameloblastoma of the mandible causing severe facial deformity is in fact disfiguring condition with unbearable social problem. Patients with extensive ameloblastoma are usually from rural areas of developing countries who delay the treatment due to the fear of surgery. Neglected ameloblastomas may become enormous and cause gross facial deformities that pose considerable problems in management. Apart from the distress due to gross facial asymmetry and regional dysfunction, patients with giant ameloblastoma convene death due to airway obstruction, starvation and complications of hypoproteinemia.

\section{References}

1. Thompson IO, Van Rensburg LJ, Philips VM. Desmoplastic ameloblastoma: correlative histopathology, radiology and CT- MR imaging. J Oral Pathol Med. 1996;25:405-10.

2. Nakasato S, Okamura S, Kudo K, Takeda Y. Gigantic ameloblasto- ma associated with secondary hypoproteinemia. J Oral Maxillofac Surg. 1991;49:764-7.

3. Kalavrezos N, Baldwin DJ, Walker DM. Giant neglected ameloblastoma: single stage treatment and clinicopathological review. $\mathrm{Br}$ J Oral Maxillofac Surg. 2008; 46:591-3.

4. Hughes CA, Wilson WR, Olding M. Giant ameloblastoma: report of an extreme case and a description of its treatment. Ear Nose Throat J. 1999; 78: 568, 570-2,574.

5. Hata H, Ebihara M, Onitsuka T, Kitagawa Y, Nakagawa M, Ota Y. Large ameloblastoma of the mandible with hypoproteinemia. Int J Oral Maxillofac Surg. 2008; 37:866-9.

6. Osaki T, Ryoke K, Nagami T, Ogawa T, Hamada T. Ameloblastoma with hypoproteinemia due to protein leakage. Int J Oral Surg. 1985;14:302-6.

7. Ueyama Y, Tsukamoto G, Matsumura T. Gigantic ameloblastoma of the mandible complicating hypoproteinemia: case report. J Craniomaxillofac Surg. 1995; 23:47-9.

8. Dunn JL, Olan WJ, Bank WO, Narang AK, Schwartz AM. Giant ameloblastoma: radiologic diagnosis and treatment. Radiographics. 1997;17:531-6.

9. Anand SV, Davey WW, Cohen B. Tumours of the jaw in West Africa. A review of 256 patients. Br J Surg. 1967; 54: 901-17.

10. Daramola JO, Ajagbe HA, Akinyemi OO. Surgical complications in mandibular resection of giant ameloblastoma. J Oral Maxillofac Surg. 1982; 40: 202-4.

11. Zemann W, Feichtinger M, Kowatsch E, Kärcher H. Extensive ameloblastoma of the jaws: surgical management and immediate reconstruction using microvascular flaps. Oral Surg Oral Med Oral Pathol Oral Radiol Endod. 2007; 103:190-6.

12. Cook J, Singh P. Tumours of the jaws. East Afr Med J. 1956; 33:383-6.

\section{Acknowledgements}

Faculty of the Departments of Oral Pathology and Microbiology, Oral Medicine and Oral \& Maxillofacial Surgery, SDM College of Dental Sciences and Hospital, Dharwad- 580009, Karnataka, India. 